Greer, C and McLaughlin, E. (2013) 'The Sir Jimmy Savile Scandal: Child Sexual Abuse and Institutional Denial at the BBC', Crime Media Culture: An International Journal, 9, 3: 243-263.

\title{
The Sir Jimmy Savile Scandal: Child Sexual Abuse and Institutional Denial at the BBC
}

\begin{abstract}
This study advances research on scandal through an empirical examination of one the most extraordinary UK institutional child sexual abuse (CSA) scandals in the post-war period. Sir Jimmy Savile (1926-2011) was a BBC celebrity, showbiz friend of the establishment and philanthropist. In October 2012, one year after his death, an ITV documentary alleged that Savile was also a prolific sexual predator who for decades had exploited his BBC status to abuse teenage girls. As we demonstrate, this incendiary documentary triggered a news media feeding frenzy that in less than one week destroyed Savile's reputation and thrust the BBC - the institution that made him a star - into a multi-faceted, globally reported CSA scandal. This study has four purposes. First, we propose a model of institutional CSA scandals that can account for critical transitions between key phases in the scandal process. Second, we apply this model to analyse the transition between the 'latent' and 'activated' phases of the Savile scandal. This transition corresponded with a dramatic transformation in the inferential structuring of Savile from 'national treasure', who had devoted decades to working with children, to 'prolific sexual predator', who spent decades abusing them. Third, we demonstrate how the BBC's denial of responsibility for Savile's sexual offending and its subsequent institutional cover-up triggered a 'trial by media' which in turn initiated the next phase in the scandal's development - 'amplification'. Finally, we consider the significance of our analysis of the Sir Jimmy Savile scandal for understanding the activation and development of scandals more generally.
\end{abstract}

Keywords: BBC; denial; institutional failure; paedophile; scandal; sexual abuse; Sir Jimmy Savile 


\section{Introduction}

Scandal has been subject to academic scrutiny from a range of disciplinary perspectives, including communications studies, sociology and, most prominently, political science (Allen and Savigny 2012; Apostolidis and Williams 2004; Cepernich 2008; Entman 2012; Gamson 2001; Garment 1991; Lull and Hinerman 1997; Marion 2010; Puglisi and Snyder 2011; Sabato 1991; Sabato, et al. 2000; Thompson 2000; Toepfl 2011; Tumber 1993, 2004). Given the frequent involvement of allegations that may result in criminal prosecution, it is remarkable that scandal has scarcely been researched by criminologists (though see Sherman 1978). This study adds to the existing body of scandal research, and raises its criminological profile, by situating the phenomenon specifically within the context of the sociology of denial (Cohen 2001; Katz 1979; Sykes and Matza 1957; Zerubavel 2006). Our empirical focus is the extraordinary scandal that followed the 2012 news media exposure of British celebrity icon Sir Jimmy Savile as a prolific sexual predator who for decades had sexually abused hundreds of teenage girls. ${ }^{1}$

The article is structured as follows. In the first part we discuss the significance of scandal as a news genre and present an analytical framework for modelling the key phases of an institutional child sex abuse (CSA) scandal. We propose that there is a gap in the existing literature regarding the transition between two key phases - 'latent' and 'activated'. In the second part we apply this model to the extraordinary scandal that followed the 2012 news media exposure of British television icon Sir Jimmy Savile's prolific sexual abuse of teenage girls. Though rumours of Savile's inappropriate sexual behaviour had been circulating for years, the scandal did not break until after his death. The 'activation' of the slow-burning 'latent' Savile scandal followed a sensational transformation of the 'inferential structures' (Greer and Mclaughlin 2010, 2012a, 2012b; Lang and Lang 1955) underpinning the development of the news story. ${ }^{2}$ We argue that, once activated, the BBC's denial of any

\footnotetext{
${ }^{1}$ Versions of this article were presented at the: Institute of Criminal Justice Research, University of Southampton; European Society of Criminology Conference, Budapest 2013; Department of Journalism, City University London; and Department of Sociology, John Jay College of Criminal Justice, CUNY. The authors would like to thank the seminar participants and $C M C^{\prime}$ 's two anonymous reviewers for their valuable feedback. ${ }^{2}$ Lang and Lang (1955) developed the concept of inferential structures to explain how the same news content could be constructed into multiple configurations, establishing selectively or partially representative frameworks of understanding - or inferential structures - within which both newsmakers and audience could
} 
knowledge of or responsibility for Savile's sexual offending triggered a 'trial by media' (Greer and Mclaughlin 2011, 2012a, 2012c) which in turn initiated the next key phase in the scandal's development - 'amplification'. The BBC stood accused by the UK press of being in denial not only about what it knew, but also about its role in enabling and covering-up Sir Jimmy Savile's sex crimes. We conclude by reflecting on the significance of the Savile scandal and the implications of our analysis for scandal research.

\section{The Significance of 'Scandal News' in the UK}

Scandal is a prime time news genre that galvanises and empowers news organisations in a ruthlessly competitive environment (Kovach and Rosenstiel 1999). Scandal news generates profit through a surge in scandalised consumers (Castells 2009: 247). It confirms the professional self-conception of journalists as vigilant watchdogs driven by a determination to 'speak truth to power', expose corruption and hold malefactors to account (Garment 1991). It feeds the national conversation (Katz, 1987). Scandal investigations have enabled UK news outlets to justify invading the privacy of individuals on public interest grounds. Not surprisingly, there is evidence that scandal hunting has become a standard feature of the UK's adversarial media and political landscapes (Campus 2010; Clark 2004; Garment 1991; Sabato, et al. 2000). Both print and broadcast UK media have been criticized for scandalising their news content (Bromley 1998; Franklin 1997; Marr 2004). However, in the volatile UK news marketplace it is the national press, with its emphasis on 'attack journalism', that have exploited the commercial appeal of 'scandal'.

Through different forms of investigative journalism, UK newspapers seek to demonstrate political and cultural power and market distinction by exposing scandals and, ultimately, taking scalps. The more important the individual or institutional scalp, the more powerful and distinctive the newspaper. Our research suggests that two categories of scandal can be distinguished, both of which do moral work by dramatizing and clarifying normative boundaries. Soft news scandals involve the transgression of superficial or tokenistic values

order and interpret the story. Over successive publications we have worked with the concept of 'inferential structures' because, we would argue, it supports a more comprehensive and concrete analysis of the definitional process in news making. The successful crystallisation of an inferential structure simultaneously frames and sets the agenda for subsequent debate around a given newsworthy issue. Framing and agenda setting are thus both dependent on the crystallisation of an inferential structure - a dominant framework of understanding - that can order and interpret meaning in a particular direction. 
that distract and perhaps intrigue, but fall short of truly scandalising British society. Soft news scandals tend to feature 'gotcha' moments as celebrities are caught in supposedly shocking situations - public unruliness, promiscuity, infidelity, substance abuse - and have become integral to a morally ambiguous celebrity culture (Postman 2005; Schickel 2000; Wilson 2010). Unless they involve or become connected with serious illegalities, or implicate the powerful, such fermented or synthetic scandals have little lasting significance. Indeed, such scandals may help to divert public attention away from more important issues. Hard news scandals, in contrast, involve acts of incompetence, immorality and/or criminality by high-profile individuals or institutions that embody clearly defined moral or ethical principles. These transgressions are sufficiently dramatic that their public revelation activates an intense negative social reaction that can have lasting reputational consequences for the protagonists (Cepernich 2008: 96; Thompson 2000: 13). Whilst both types of scandal can redefine the present, in liberal democracies hard news scandals can rewrite history by destroying the careers and private lives of public figures, de-legitimising institutions and destabilising governments. Some hard news scandals grip society immediately. Others are slow-burning, snaking through countless twists and turns before gathering public traction. It is this latter type of hard news scandal that provides the empirical focus in this article.

\section{The Dynamics of Institutional Child Sexual Abuse (CSA) Scandals}

The longstanding taboos that kept CSA marginalised from UK public debate were finally challenged in the 1980 s by sustained feminist campaigning, media coverage and public testimony from individual survivors (Angelides 2005; Department of Health 1991; Department of Health and Social Services 1982; Greer 2012; Kitzinger 2001, 2004; La Fontaine 1990). Kitzinger (2001: 91; see also Radford, et al. 2011) notes that news media exposure 'fundamentally transformed private and public discourse' about CSA. Because news coverage of abuse continued to be shaped by the dominant inferential structures of 'predatory paedophiles', little attention was paid to more prevalent problems of institutional and familial abuse (Critcher 2002; Silverman and Wilson 2002). However, a succession of scandals since the 1980s exposed the sexual abuse of children in care homes, private schools and religious institutions, and forced the problem of institutional abuse onto 
the political agenda (Davidson 2008; Franklin and Parton 1990; Jenkins 1992; Kitzinger 1996; Moore 1996; Silverman and Wilson 2002). Institutional scandals resulting from silence, stonewalling, denial and deception led to the establishment of official inquiries that raised further public awareness of this previously hidden crime (Barter 1998; Corby, et al. 1998; Department of Health 1991; Waterhouse 2012). As a result, it is no longer possible for British society to deny knowledge of CSA in institutional settings.

Based on our reading of the available research and official reports, we would propose that an institutional CSA scandal progresses through the following phases. In the 'latent' phase, the sexual abuse is known to or suspected by others, but remains secret or concealed. Gossip, hearsay, rumour and speculation produce 'open secrets' (Kipnis 2010). There may be accusations and complaints, or even threats from those 'in the know' about blowing-thewhistle. Yet so long as the abusive behaviour is not made public, the scandal will not be 'activated'. To progress from the 'latent' to the 'activated' phase, a news organisation must not only know about the alleged sexual abuse, but decide to report it and, crucially, to name the alleged abuser(s). Institutional CSA is highly newsworthy and can be commercially and politically explosive. Yet doubts about an allegation's reliability and the risk of libel and defamation charges by powerful individuals or institutions may discourage news agencies from reporting allegations that they think, or even know, to be true (Basinger and Rottinghaus 2012; Sabato, et al. 2000: 79). For these reasons, even in an era of information overload, scandal activation is not inevitable. Once reported, few crimes generate more vociferous and collective public outrage than institutional CSA, particularly when connected with allegations of 'institutional failure' and 'cover-up'. The typical institutional reaction, which Gardner (2012) understands as a form of 'institutional narcissism', is to prioritise at any cost the protection of the institution's reputation from negative publicity. The primary techniques of reputation management, seemingly woven into the fabric of powerful institutions accused of CSA, are concerted ignorance and public denial of wrongdoing. Public denial drives and animates an activated institutional CSA scandal. Cohen (2001) identifies three distinct, though at times intersecting, techniques of denial: literal, interpretive and implicatory. With literal denial, the facts or knowledge of the facts about the alleged CSA are rejected by the institution. Literal denial may be genuine, it may be a means of disregarding a 'truth' too traumatic to acknowledge, or it may be a form of 
deliberate lying. With interpretive denial, the facts of the CSA are not denied, but they are given a different institutional meaning from that which seems evident to others: the abuse is 'cognitively reframed and then reallocated to a different, less pejorative class of event' (Cohen 2001: 106). Finally, implicatory denial accepts the facts of the CSA and their conventional interpretation, but rejects their institutional significance or implications. As we demonstrate throughout this article, powerful institutions can deploy significant public relations resources to deny and/or suppress allegations of individual and institutional wrongdoing. Yet, since public naming requires editorial assurance that there is sufficient evidence to substantiate the allegations, the default news media position at the point of scandal activation is that the accused is guilty. In most cases, therefore, denial is interpreted as untruthful and, as such, deliberate and public lying. Those accused of lying about or covering-up CSA will be plunged into a volatile 'trial by media' (Greer and McLaughlin, 2011, 2012a, 2012c) in which claim and counter-claim are publicly scrutinised for validity.

For a CSA scandal to enter the 'amplification' phase the transgressions of individuals needs to be connected with allegations of 'institutional failure' that elevate their implications to systemic levels. 'Institutional failure' can range from procedural incompetence and mismanagement to a range of criminal behaviours including non-disclosure and deliberate cover-up. Truth-seeking investigations build scandal momentum by unearthing evidence to corroborate the primary transgressions and digging deeper in the hope of discovering new or supplementary accusations and accusers. In the amplification phase news media attention shifts to the institutional context which facilitated the child sexual abuse, and enabled its subsequent denial and cover-up. It is in this phase that we hear talk of cultures of denial, cover-up and impunity. An amplifying CSA scandal can implicate and expose failings not only within a single institution, but across a range of institutions. Scandal amplification creates a swarming effect as news organisations compete to scoop their market rivals by printing fresh allegations and denunciations and reinforcing the public image of the accused as guilty.

The 'justice' phase of an institutional CSA scandal comprises repetition of the primary transgressions, new disclosures of incriminating evidence and supplementary transgressions, and intensifying news media denunciation of the individual(s) and institution(s) involved. Faced with mounting evidence of guilt, the accused may choose to 
tender a public confession and apologise. As many public figures have learned to their cost, continued denial or defiance is self-defeating, merely intensifying 'trial by media' and the public censure once guilt is confirmed. Public censure consists of a range of status degradation ceremonies, from public shaming through to resignation, dismissal, criminal prosecution and imprisonment (Cavender, et al. 2010).

The crystallisation of CSA scandals across myriad media platforms leaves a networked imprint on web consciousness, rendering closure of the digital archive impossible (Demott, 2008: 475). Because of the noxious nature of the stigma attached to child sexual abuse, there is no such thing as a de-activated CSA scandal. Those found guilty in the 'court of public opinion', even if the case never reaches a court of law, forfeit the right to be forgotten, or forgiven. They can be subjected to endless 'trial by media'. In the remainder of this article, we analyse the transition between the 'latent' and 'activated' phases of the ongoing Sir Jimmy Savile scandal, and the techniques of institutional denial that resulted in the BBC's unprecedented 'trial by media' and rocked the corporation to its core.

\section{The Study: Methodology and Data Sources}

In this study, a qualitative thematic press analysis was used to investigate the transition between the 'latent' and 'activated' phases of the slow-burning Savile scandal. This analysis was informed by two primary research questions:

a) What precipitated the transition between the 'latent' and 'activated' phases of the Savile scandal?

b) What was the BBC's institutional reaction to the 'activation' of the Savile Scandal, and how did this reaction influence its subsequent development?

The press analysis presented in this article was divided into three stages. Stage one involved a Nexis search of the UK's eight national newspapers between 29 October 2011, the day Sir Jimmy Savile died, and 6 October 2012, two days after the ITV documentary was broadcast. Stage two involved the analysis of these newspapers in original hard copy to understand the wider context of coverage, including other stories that were competing with the Savile scandal for front-page status. Stage three involved cross-referencing our press analysis with supplementary material from broadcast and online news outlets, blogs and official reports. 
The reports from the Pollard inquiry into BBC Newsnight's investigation of the allegations against Sir Jimmy Saville, the Metropolitan Police Service (MPS), Crown Prosecution Service (CPS), and her Majesty's Inspectorate of Constabulary (HMIC) were vital because they provide a multi-institutional perspective on the transition from 'latent' to 'activated' scandal. These reports were sources against which we could check our analysis for interpretive bias, and 'official' timelines against which we could verify our timeframe. Factchecking was also facilitated by Sir Jimmy Savile's autobiography (Savile 1974) and an authorised biography (Bellamy 2012). Invaluable background information on the production and reception of the ITV documentary Exposure: The Other Side of Jimmy Savile was obtained through an interview with Mark Williams Thomas, the former detective who produced and presented the documentary.

\section{Scandal Free: The Public Validation of Sir Jimmy Savile as 'National Treasure'}

Sir Jimmy Savile's death on 29 October 2011, two days short of his $85^{\text {th }}$ birthday, generated a UK news media reaction that validated a default inferential structure. Savile was memorialised in features and obituaries as a 'national treasure' who lived his life in the glare of publicity. Savile claimed to have been a DJ before the term was invented, using twin turntables and a microphone in 1947 and running the world's first dance hall disco in 1948. On New Year's Day 1964, he presented the first ever edition of BBC's Top of the Pops and over the next forty years hosted three-hundred episodes of the legendary music programme. It was on Top of the Pops that Savile, with his hallmark peroxide-blond hair, demonstrated an outlandish taste in fashion, jewellery and cigars and deployed his famous catch phrases or 'Savilisms', 'How's about that, then?' and 'Now then, now then'. Savile would become even more famous for Jim'll Fix It, a BBC television show that ran from 1975 to 1994 . At the height of the show's popularity, approximately 20,000 children a week would write in asking Savile to 'fix it' for them to, for example, meet pop stars, fly on Concorde, or ride on the world's tallest rollercoaster. Savile presented each lucky child who appeared on the show with a medal engraved with the words Jim Fixed It For Me.

A friend of the famous and powerful, Savile was appointed OBE in 1971. He received a knighthood from the papacy in 1982 and the Queen in 1990 for his charity work, which raised tens of millions of pounds. Following his death, there were tributes from Buckingham 
Palace, politicians, celebrities and representatives of the charities, hospitals and children's homes that benefitted from his good deeds. The then Director General of the BBC, Mark Thompson, made a public statement eulogising the veteran broadcaster's unique place in British popular culture and his untiring charitable work. Footage and images of Savile signified a golden era when the BBC dominated UK broadcasting. Louis Theroux, the presenter who made the last documentary on Savile in 2000, said: 'Jimmy loved to entertain, to dazzle, and to joke. In an age of agents, PRs, and media handlers, he was completely the opposite, utterly free of showbiz airs. He was as far from being a diva as one could imagine. There won't be another one like him' (Sunday Telegraph, 30 October 2011: 23).

Sir Jimmy Savile's 'national treasure' status was reinforced with a celebratory funeral that spanned three days between 8 and 10 November 2011. His gold-coloured coffin was displayed in his home city of Leeds so the public could pay their respects and sign a book of condolences. The next day, Royal Marine pallbearers carried Savile's coffin into St Ann's Roman Catholic Cathedral. The Bishop of Leeds presided over a televised requiem mass attended by a congregation of 700 mourners. The default inferential structure was reproduced and reinforced across newspaper coverage, and recalled Savile's most famous catchphrases:

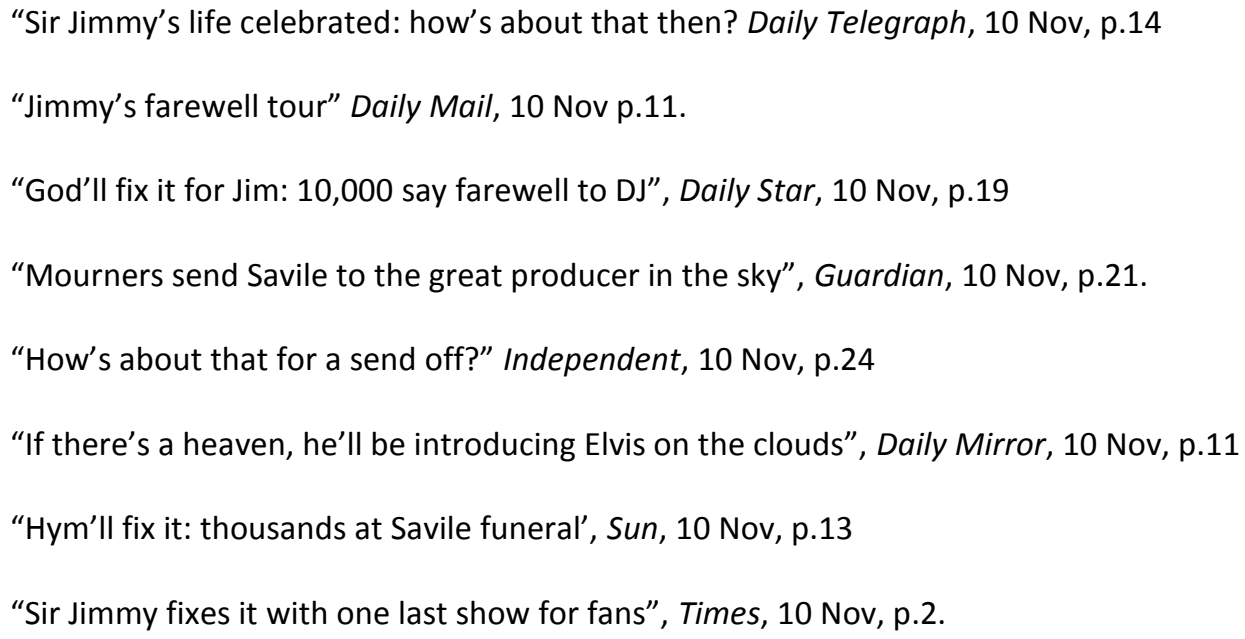

The symbiotic relationship between Savile and the BBC was reflected in a series of affectionate tribute programmes: Sir Jimmy Savile: As it Happened, (11 November), Sir Jimmy Savile: In His Own Words (Christmas Day), Jim'll Fix It (Boxing Day), and Sir Jimmy Savile at the BBC (28 ${ }^{\text {th }}$ December). Several broadsheets noted that Savile's critics had 
labelled him a self-publicist who would do anything to ingratiate himself with the British establishment. His lifelong bachelor status, idolisation of his mother ('the Duchess') who lived with him until she died, and antiquated views on 'ladies' had also generated speculation and innuendo about his sexuality:

'Jimmy Savile was a quirky, complex man who never married, claimed he never had time to fall in love, and was known to register prickly aggression at the mention of women and sex in relation to himself' (Times, $29^{\text {th }}$ October: $x x$ ).

'Rumours of under-age sex circulated for some years, although the fact that no allegations of impropriety ever appeared in print seemed to confirm Savile's own insistence that he had 'no past, no nothing' (Daily Telegraph, $29^{\text {th }}$ October: $\mathrm{xx}$ ).

'When asked about children, he said: 'I couldn't eat a whole one. . . hate 'em.' The only reason he got on with children, he said, was because he did not like them. But later he said he only said he hated children to stifle rumours about his sexual preferences'. (Observer, $30^{\text {th }}$ October 2011: xx).

However, any counter-characterisation was eclipsed by the default inferential structure that framed Savile as 'national treasure'.

\section{The Latent Scandal: From Gossip and Rumour to News Media Investigation}

On 8 January 2012 the Sunday Mirror claimed that Newsnight, the BBC's flagship current affairs programme, had abandoned an investigation into allegations that Sir Jimmy Savile had sexually assaulted underage girls in the 1970s. It was alleged that the news story, which included victim testimony, was 'killed' because it would have undermined the BBC's planned tribute programmes. Newsnight had established that a 2009 Surrey Police investigation of an allegation against Savile of indecent assault at an approved school for teenage girls had been dropped due to insufficient evidence (Sunday Mirror, 8 January 2012: 11). The following day the Daily Mail and the Sun repeated the story. The Daily Mail (9 January 2012: 14) noted that, 'Corporation bosses had denied any connection between the tribute and the decision not to screen the item'. Both newspapers also included statements from Savile's family and friends, who viewed the allegations as a defamatory attempt to destroy the deceased celebrity's reputation.

On 8 February one of Britain's leading political blog sites, the Guido Fawkes blog, named the cancelled Newsnight story as a 'potential BBC scandal': 
'BBC Jimmy Savile 'Cover Up Scandal' Coming: Whispers in the wind of a potential BBC scandal developing. Guido understands that tomorrow's edition of The Oldie magazine will shed some more light on rather unpleasant allegations about the late Sir Jimmy Savile and why a Newsnight report suggesting that he molested underage girls was mysteriously spiked.'

The Oldie, a small circulation monthly news magazine (http://www.theoldie.co.uk/savilerow), also questioned the BBC's official account and warned 'that the matter is not at an end. Many of Savile's other victims - and those of other celebrities with whom he mixed in the 1960 s and 70 s - are preparing to speak out'. It also described a recriminatory atmosphere inside the $\mathrm{BBC}$ regarding the decision to cancel the Newsnight story. The Guardian (9 February) and the Daily Telegraph (10 February) ran similar reports, also sourced from The Oldie magazine. According to the Daily Telegraph (10 February: 12) the BBC stood accused of 'covering up the allegations to protect the corporation's reputation'. A BBC source was quoted as saying: 'The extreme nature of the claims about Savile meant that the Newsnight report was going to seriously compromise the lavish BBC tributes scheduled to run later the same month. And second, the allegations directly involved the BBC, in that the woman who gave the interview said that she and others were abused by Savile on BBC premises' (ibid.). The Daily Mirror (11 February) and the Daily Express (14 February) also ran the story.

For this brief period, the default inferential structure framing Savile as 'national treasure' was challenged publicly across mainstream news outlets and blogs. There would appear to have been sufficient 'precipitating disclosure' (Thompson 2000: 74) for the activation of a major scandal. The allegations of sexual assault against Savile were reinforced with claims that victims were now willing to speak in public, the abuse had happened on BBC premises, the BBC had been involved in covering-up Savile's depredations, and that one police force and the CPS knew about the allegations. Savile was not alive to deny the allegations, nor to threaten legal action. Yet the Savile scandal remained 'latent'. A chilling effect may have resulted from heightened sensitivities around unethical press practice in light of the Leveson inquiry ${ }^{3}$, and the fact that a well-resourced Newsnight investigation could not establish the

\footnotetext{
${ }^{3}$ Following the phone-hacking scandal that led to the closure of British Sunday tabloid The News of the World, and arrests of News International and other journalists, the government established a public inquiry to investigate the culture, practices and ethics of the press and, in particular, the relationship of the press with the police and politicians. Lord Justice Leveson was appointed as Chairman of the Inquiry. The Inquiry Report was published in November 2012, and is available here: http://www.levesoninquiry.org.uk/about/the-report/.
} 
required level of proof to broadcast the allegations. What is most striking is that the following period of news coverage, from March to July 2012, reaffirmed the default inferential structure by focusing on the 'fortune' that that Savile had bequeathed to charity. The Savile allegations resurfaced on 5 August 2012 with the Sunday Mirror and Mail on Sunday reporting that the ITV documentary team who had produced To Catch A Paedophile (2009) had gathered enough evidence to name Sir Jimmy Savile as a prolific sexual predator. Beneath the headline 'Sir Jim named as a paedophile in TV shocker', the Sunday Mirror disclosed that the programme would be broadcast in a prime-time slot before the first anniversary of Savile's death on 29 October 2012. It would include interviews with Savile's victims and re-examine the police decision not to prosecute Savile. The Mail on Sunday's 'Documentary claims Jimmy Savile abused teenage girls' was a more cautious story, noting that ITV had not yet committed to broadcasting the investigation, 'which one programme insider said would 'shock the nation' (5 August: 7). The story was repeated the following day in the Daily Mirror: 'TV show to claim Savile was paedo', and the Sun: 'TV show to reveal Savile as 'a paedo' (6 August 2012). The inferential structure framing Savile as 'national treasure' was again being challenged, this time with a potentially devastating 'paedophile' counter-characterisation. Once again, however, the 'latent' scandal failed to initiate any form of newspaper investigation, and did not progress to the 'activated' phase. On 21 September, passing coverage reported the unveiling of an ostentatious headstone on Savile's grave. Later that month, those same newspapers that had printed the 'paedophile' allegations celebrated the sale of Savile's personal belongings to raise money for his favourite charities (Daily Mirror and Sun, 28 September).

\section{The Activated Scandal: Naming Savile as 'Prolific Sexual Predator'}

During the last week of September 2012, ITV announced that on 3 October Exposure: The Other Side of Jimmy Savile would name Savile as a prolific sexual predator who for decades had offended with impunity inside UK public institutions. The announcement coincided with a string of 'sex predator' stories that were dominating the headlines. The documentary would implicate the BBC, claiming that: a) sexual assaults by Savile and other celebrities had taken place on BBC premises; b) Savile's sexual depredations were 'common knowledge' in the $\mathrm{BBC}$, but nothing was done to protect teenage girls from victimisation, and; $\mathrm{c}$ ) 
Newsnight had been blocked from broadcasting the allegations. The scandal's progression from its 'latent' to 'activated' phases was finally initiated as the documentary forced a reaction from Savile's family, friends and supporters, the BBC, and the rest of the British news media.

\section{BBC Reaction I: Literal Denial}

Savile's family, friends and institutional supporters reacted to the ITV allegations with literal denial. Not only were the accusations baseless, it was argued, they would also jeopardise Savile's charitable legacy. ITV was accused of the lowest form of gutter journalism. The Trustees of the Sir Jimmy Savile Charitable Trust stated:

\footnotetext{
'It is well known that Surrey Police investigated an allegation of underage sexual abuse against Sir Jimmy during his lifetime and determined that no action be taken against him. At no time was he found to have committed any such serious offences. We cannot help but wonder why a programme containing these allegations has been made after his death, at a time when he cannot defend the claims nor can any such allegations be fully verified. The publication of such grave allegations may affect the charitable trust, which supports so many good causes. The trustees worked with and became friends with Jimmy during his lifetime. They are personally outraged and they have no reason to believe these allegations' (Times, 29 September, 2012: 6).
}

The BBC's literal denial was comprehensive, and its self-exoneration absolute. The corporation insisted that there was no institutional record of complaints about Savile. The allegations were from another era and nothing more could be known or done about Savile:

\footnotetext{
'The BBC has conducted extensive searches of its files to establish whether there is any record of misconduct or allegations of misconduct by Sir Jimmy Savile during his time at the BBC. No such evidence has been found. Whilst the BBC condemns any behaviour of the type alleged in the strongest terms, in the absence of evidence of any kind found at the BBC that corroborates the allegations that have been made it is simply not possible for the corporation to take any further action'.
}

This 'guilt free' statement made no mention of the cancelled Newsnight investigation. Newsnight released its own aggressive statement, deploying both literal and interpretive techniques of denial, to reject the ITV allegations and absolve itself of responsibility (Sunday Telegraph, 30 September, 2012: 5): 
'It is absolutely untrue that the Newsnight investigation was dropped for anything other than editorial reasons. We have been very clear from the start that the piece was not broadcast because the story we were pursuing could not be substantiated. To say otherwise is false and very damaging to the BBC and individuals. To allege that we are withholding evidence from the police is also damaging and false. The notion that internal pressure was applied appears to be a malicious rumour.'

The Newsnight statement attempted to shift attention onto those who it accused of ulterior motives in circulating a 'false' and 'malicious rumour'. Despite the strenuous denials, the press reaction over the weekend of 29 and 30 September shifted from reporting the ITV allegations as unconfirmed to accepting them as substantiated. Though, as we have evidenced above, allegations about Savile's sexual offending had been published before, they were repackaged as shocking and previously unknown scandalous revelations:

\footnotetext{
"Savile accused of sex attacks on young girls" (Daily Express, 29 September 2012)
}

"TV host Jimmy Savile sexually abused 10 girls during career peak" (Daily Mail, 29 September 2012)

"Savile alleged to have abused girls" (Guardian, 29 September 2012)

"Savile 'sexually abused girls'” (Daily Telegraph, 29 September 2012)

“Women's shock TV claim that DJ Savile attacked them as kids (Sun, 30 September 2012)

"Savile is branded 'paedo' on telly show" (Sun, 30 September 2012)

"The shocking evidence that Jimmy Savile DID abuse underage girls - by 4 of his victims" (Mail on Sunday, 30 September 2012)

“Jimmy Savile: 'a predator on young girls'” (Independent on Sunday, 30 September 2012) Jimmy Savile raped me: TV legend 'attacked' FIVE teens (Daily Star, September 30, 2012)

"Jimmy Savile raped me: woman was 15 at the time of sex attack" (Sunday Mirror, 30 September 2012)

“He was a predator of young girls \& he raped me" (Sunday People, 30 September 2012)

“Jimmy Savile 'abused 14 year old girl in his BBC dressing room” (Sunday Times, 30 September 2012)

"Sordid truth about Jimmy Savile by sex abuse victims" (Sunday Express, 30 September 2012)

“Jimmy Savile 'abused us at BBC' claim women” (Sunday Telegraph, 30 September 2012)

“BBC denies cover up over Sir Jimmy Savile allegations” (Sunday Telegraph, 30 September 2012)

Now furnished with evidence of Savile's 'guilt', the Sunday press coverage of 30 September developed the story, reproducing in detail the claims of Savile's alleged victims. The BBC's literal denial was undermined by testimony from former colleagues, who insisted that the celebrity's sexual interest in teenage girls was an 'open secret'. 
The ITV documentary was given credibility by a statement from Esther Ranzen, former BBC presenter, friend of Jimmy Savile and founder in 1986 of the UK's first telephone helpline for abused children, ChildLine. Ranzen's role in ChildLine transformed her into a high-profile international campaigner on child abuse issues. She now declared across multiple press interviews that the ITV investigation had convinced her of Savile's guilt (Mail on Sunday, 29 September 2012: 5).

The Sunday Telegraph, Sunday Times, Sunday Mirror and Mail on Sunday moved quickly to initiate a 'blame game' (Hood 2011), linking Savile's abuse with institutional cover-up at the BBC. Obliterating the image of Savile as 'national treasure', the Sunday Mirror's editorial, 'Savile secrets had to be told', was the first newspaper to name the sustained sexual abuse as a 'scandal':

'The scandal of his exploits - and their lifelong effects on his victims - is made even worse by being kept secret for so long. Questions have been raised as to whether the Establishment - in this case senior people at the BBC - who had suspicions about Savile should have investigated to stop this sexual predator. His victims have the right to tell their stories. And the media is right to report them today' (30 September: 14).

The story gained traction across news outlets in the run-up to Wednesday 3 October, the day the ITV documentary would be broadcast. Press reporting gave licence to social media sites to regurgitate old rumours and allegations about Savile, which were in turn reported by sections of the press. Former Radio 1 DJ, Paul Gambaccini, broke the silence of the group of BBC DJs Savile had worked with at the height of his fame, confirming that within the BBC Savile's sexual predilections had been an 'open secret'. Reputation, fame and social standing had empowered Savile and silenced colleagues and the news-media. Though it had held firm for months following Savile's death, despite the periodic reporting of rumours and allegations, the inferential structure framing Savile as 'national treasure' now lay in ruin. An alternative inferential structure crystallised rapidly around the interconnected news frames of Savile as 'prolific sexual predator' and 'institutional cover-up' at the BBC. Once 'latent', the Savile scandal was now 'activated'. The BBC's denial of all knowledge of Savile's offending triggered an aggressive press reaction. That reaction would intensify and expand the attribution of blame, amplifying the scandal and placing key individuals (alive and dead) and institutions on 'trial by media' for Savile's sexual assaults. 


\section{BBC Reaction II: Interpretive and Implicatory Denial}

On the day of the ITV documentary newspapers carried reports that ten women had broken decades of silence to provide corroborating accounts of sexual assault by Savile and other BBC celebrities, most notably convicted paedophile glam rock star Gary Glitter. At this point, the $\mathrm{BBC}^{\prime}$ s institutional response compartmentalised. An official statement read as follows:

\footnotetext{
'A number of serious and disturbing allegations have been made over the past few days about the sexual abuse of teenage girls by Sir Jimmy Savile. Some of these allegations relate to activity on BBC premises in the 1960s and 70s. We are horrified by allegations that anything of this sort could have happened at the BBC - or have been carried out by anyone working for the BBC.

They are allegations of a serious criminal nature which the police have the proper powers to investigate. So we have today asked the BBC Investigations Unit to make direct contact with all the police forces in receipt of allegations and offer to help them investigate these matters and provide full support to any lines of inquiry they wish to pursue. The BBC is working closely with the relevant police authorities. They have asked us to make clear that anyone affected by the issues raised in the ITV programme can contact the NSPCC Helpline on 08088005000 or their local police force'.
}

Literal, interpretive and implicatory techniques of denial were evident in the BBC's attempt to neutralise the 'activated' scandal. Despite the now widespread understanding that rumours and allegations against Savile had been circulating for years, there was literal denial of historic knowledge in the corporation's horror at discovering that an employee could have perpetrated sexual assaults on BBC premises. This literal denial of historic knowledge facilitated an interpretive denial of historic culpability: there was no acknowledgement of the widespread criticism that the $\mathrm{BBC}$ had failed to take seriously and investigate rumours and allegations of sexual abuse in the past. Rather, the focus was placed on the present and future through pledging to cooperate fully with a criminal investigation. Finally, there was implicatory denial: even if abuse had taken place, it was not the BBC's responsibility to investigate. Only the police could do that. As with its previous statement, the corporation made no reference to the cancelled Newsnight investigation.

In a separate statement, Peter Rippon, the executive producer of Newsnight, published an outright rejection of the accusations surrounding the cancelled investigation:

'There has been a lot written about why I took the decision not to run a story into allegations of sex abuse by the former BBC presenter Jimmy Savile. It has been suggested I was ordered to do it by my 
bosses as part of a BBC cover-up. It has also been suggested that we deliberately withheld information from the police. Both these allegations are totally untrue and despite consistent strong denials keep getting repeated.'

Rippon re-emphasised that the $B B C$ investigation had been cancelled because of the inability to substantiate allegations that the police and prosecution service had dropped the case against Savile because he was too old and infirm to stand trial. The investigation had uncovered no evidence against Savile or identified witnesses that the police were not already aware of. Nor had it found any evidence implicating the BBC in Savile's sexual assaults. Finally, Rippon insisted that there had been no disagreements inside Newsnight regarding the decision to cancel the Savile investigation.

Newspaper editorials expressed incredulity at the BBC's continued denial and its inability to appreciate the reputational damage resulting from the rapidly escalating scandal. Rippon's denials were immediately undermined by leaks from inside the BBC. George Entwistle, the newly appointed Director General and former head of BBC programming, was now personally implicated in the unfolding scandal:

The BBC rightly promises to co-operate with the police over the investigation into the Jimmy Savile sex abuse scandal. But it also faces questions over why it dropped a Newsnight probe into the disgraced TV star. Day-by-day, the allegations against Savile become more appalling. The least that his victims are owed is that the whole truth finally comes out' (Sun, editorial $3^{\text {rd }}$ October).

'... if they had strong suspicions about the man, why did they not speak out earlier. It is understandable that abused and traumatised children would be fearful of accusing a powerful figure such as Savile. High profile personalities such as Rantzen and Gambaccini have no such excuse' (Daily Star, editorial $3^{\text {rd }}$ October)

'No doubt there will be obfuscation and denials. But if the BBC does not treat this seriously, it will have little of its precious reputation left to save' (Daily Mail, editorial $3^{\text {rd }}$ October)

'The public needs a full explanation first, of how such conduct could be not just overlooked by the national broadcaster, but even facilitated; and second, of why the BBC failed to investigate properly, both during his life and after his death. If the reason for dropping the Newsnight report turn out to be unsatisfactory, then George Entwistle, the new Director general must be ruthless" (Daily Telegraph, editorial, 3 October).

Alongside the editorials, commentary pieces in the Guardian, Daily Express, Daily Mail and Independent reflected on how the BBC's celebrity culture had normalised Savile's offending and enabled him to avoid detection. 


\section{From Revered to Reviled: Savile's Undeniable Guilt and the BBC's 'Trial by Media'}

With the broadcasting of the heavily-trailed ITV documentary, the BBC was plunged into an institutional crisis. Exposure: the Other Side of Jimmy Savile put Savile and the BBC on 'trial by media' (TBM). Evidence for the prosecution was the graphic testimony of five women who explained how as teenagers they were induced or coerced into sexual acts by Savile, and three independent witnesses who had observed Savile having sex with underage girls. The women also detailed the long-term damage caused by the assaults. Savile's guilt was presented as beyond doubt. By linking Savile's offending directly to his BBC persona and television shows, victim and witness testimony ensured that the BBC's guilt of institutional failure and cover-up would now be the focus. Accordingly, the programme was driven by two incendiary accusations. The first was that for decades Savile had used his prime-time BBC programmes and celebrity status as a means to attract and sexually assault star-struck teenage girls: BBC studios and changing rooms were in effect sex crime scenes. The second accusation was that, within the BBC and across the entertainment industry, 'everyone knew' of Savile's sexual predilections but nobody challenged him. As a powerful and wellconnected BBC celebrity and acclaimed charity worker, Savile was described as being untouchable. Television footage and 'Savilisms' were re-framed to evidence tell-tale signs of his sexual proclivities. The Exposure team represented Louis Theroux's documentary from 2000 , in which Savile was challenged to deny that he had paedophile tendencies. They also reconsidered Savile's off-the-record defence of convicted paedophile glam rock star Gary Glitter. The programme functioned as a devastating 'degradation ceremony' (Garfinkel 1956; Lofland 1969: 158) that visually and discursively retrofitted Savile as a 'prolific sexual predator' who had operated within an institutional culture of impunity. The case was reinforced by lan Glen QC, a legal expert on child abuse, who confirmed that the evidence was robust enough for Savile to be arrested and prosecuted if he were still alive. The documentary closed with a visibly shocked Esther Rantzen admitting that she had been in denial about Sir Jimmy Savile and that the case against him was irrefutable. No-one appeared on the programme to defend Savile.

The ITV documentary propelled the Savile scandal to front-page status across all UK outlets. The dominant inferential structure of Sir Jimmy Savile as a 'prolific sexual predator', whose 
offending had been known about and covered-up by the BBC, was reinforced over the next two days. No national news outlet deviated from this characterisation and no-one came forward to defend Savile's reputation. The national press demanded answers. Four mutually reinforcing questions informed the press' collective response, and drove the next phase in the scandal's development - from 'activation' to 'amplification'. These questions locked the $\mathrm{BBC}$ into the centre of the Savile scandal.

The first question asked: 'what was the full nature and extend of Sir Jimmy Savile's sexual offending?' By now the forty victims who had already contacted the police and other agencies were deemed to be the tip of the iceberg: it was anticipated that the 'Savile effect' would encourage more victims, from a variety of institutional contexts, to come forward. The rapidly multiplying allegations, many of which implicated other BBC celebrities, were sufficient for police forces to launch a series of criminal investigations. This development fuelled claims of a culture of sexual misconduct at the BBC.

The second question asked: 'who at the BBC shared the guilt for Savile's sexual offending, and what was their role in the cover-up?' Retired BBC press officer, Rodney Collins, confirmed that Douglas Muggeridge, then Controller of BBC Radio, was aware in 1973 of allegations regarding Savile's interest in underage girls. Collins insisted that Muggeridge's close colleagues would have known about the allegations, and claimed that the tabloids did not expose Savile because of his celebrity status and charity work:

"Radio 1 boss 'knew of Savile abuse claims'” (Daily Telegraph, October 4, 2012)

“Radio 1 boss "knew Savile was abusing young girls" (Independent, October 4, 2012)

"Former Radio 1 boss 'knew of Savile rumours'” (Daily Express, October 4 2012)

"Rumours and fears at the BBC" (Daily Express, October 4, 2012)

“BBC 'was aware of Savile sex abuse allegations in 1973’ (Times, October 4, 2012)

"Radio 1 boss knew of Savile child sex claims back in '73: pressure on BBC over Jimmy shame" (The Sun, October 4, 2012)

"I Warned BBC on Savile 40 years ago" (The Sun, October 4, 2012)

“Jimmy Savile 'untouchable' by press in 1970s, says former editor" (The Guardian, October 4, 2012)

"BBC chiefs knew of allegations in the 1970s" (Daily Mail, October 4, 2012) 
Establishing the identities of a supporting cast of BBC personnel who, through indifference, assistance and/or cover-up, had enabled Savile to work with children and teenagers, provided a lengthy list of possible follow-up targets for 'trial by media'.

The third question asked: 'did Newsnight drop its investigation because of BBC plans to screen tribute programmes to Savile?' Politicising the scandal, Members of Parliament demanded a public inquiry to establish the truth about the BBC's knowledge of Savile and its reasons for cancelling the Newsnight investigation. For Conservative MP, Phillip Davies, the $B B C$ 's reaction to the Savile allegations bore

'...all the hallmarks of a political scandal where an MP makes denial after denial in a desperate attempt to keep their job - only for the whole house of cards to come crumbling down. The attitude of the BBC seems to have been that because these allegations were from a long time ago they needn't investigate thoroughly. They have been on the back foot, fire-fighting. They desperately need to get on the front foot. The new Director General George Entwistle must establish quickly, but thoroughly, exactly who at the BBC was aware of the allegations' (Times, 5 October).

It was also confirmed that politicians were pressing for the BBC Director General to face cross-examination in the House of Commons. Editorials in the Times, Daily Mail, Sun and Daily Mirror and hard-hitting opinion and commentary pieces focused on the BBC's denial of knowledge and responsibility. Most directly critical of the BBC were Andreas Whittam-Smith (Independent), Trevor Kavanagh (Sun), and Richard Littlejohn (Daily Mail). For Richard Littlejohn the BBC had behaved in a criminal manner:

'For four decades, the BBC conspired in a cynical, calculated cover-up. Even after Savile died, Newsnight was prevented from telling the victims' stories. There was a Cosa Nostra code of omerta when it came to claims Savile had assaulted young girls on BBC premises. If similar allegations had been made against a prominent Catholic priest or, even better, a well-known Tory MP, Panorama ${ }^{4}$ would have been put on a war footing and the BBC News operation would not have rested until the culprit had been exposed and prosecuted to the fullest extent of the law.'

For Whittam-Smith (Independent) and Kavanagh (Sun) it was vital to establish an independent inquiry:

'At a certain point, the persistence of rumours, of a strength sufficient to generate a Newsnight investigation, has to be taken as the proverbial smoke that indicates fire. No wonder the BBC said on Tuesday evening that it was "horrified by allegations that anything of this sort could have happened at the BBC - or have been carried out by anyone working for the BBC". Too late. Now the chairman, Lord

\footnotetext{
${ }^{4}$ Panorama is a BBC current affairs programme that features investigative reports on a range of issues.
} 
Patten, must follow in the Archbishop of Canterbury's footsteps and order an investigation of what seems to have been the Corporation's sins of omission' (Whittam-Smith).

'Rumours of this abuse of power were widely whispered. Why did the BBC not take action then to investigate? ... The Savile case is a horrific black mark against the Corporation. How much more evidence is required before the Government orders a proper, thorough and independent public inquiry?' (Kavanagh).

The fourth question asked: "how could Savile and those who colluded with Savile be punished?' For Savile himself, now deceased and beyond criminal justice, the only process remaining was 'media justice' (Greer and McLaughlin, 2012a). Institutions associated with Savile came under immediate press pressure to undertake a remarkable process of 'deSaviling'. The degradation ceremony that began with the Exposure documentary now spread across the UK as Savile's public biography - having deteriorated from 'national treasure' to 'prolific sexual predator' - was now to be expunged entirely. By removing all footage of Savile from its website, the BBC was in effect altering the historical record of the relationship between the corporation and the disgraced celebrity presenter. Newspapers reported that Scarborough council would be removing a plaque honouring Savile outside his flat because it had been defaced with the words 'paedophile' and 'rapist'. Glasgow council had already removed a statue of Savile from a public leisure centre, and plans to convert his Scottish cottage into a retreat for disabled war veterans were put on hold. Savile's ostentatious gravestone, once viewed as a fitting tribute to a 'national treasure', was redefined as an obscenity and an internet campaign sought to have it removed. A government e-petition was inundated with signatures demanding that Savile be stripped of his knighthood. The charities funded by Savile came under public pressure to renounce their disgraced patron and atone by transferring funds to child abuse organisations. Through implicating any institution Savile had been in contact with, the scandal quickly entered its 'amplification' phase and spread across the charitable, health and voluntary sectors.

\section{Conclusion}

The objective of this study was to model the dynamics of institutional CSA scandals and to test key phases of this model through an empirical analysis of the Sir Jimmy Savile scandal. Accordingly, we analysed the shift from a 'latent' and slow-burning child sexual abuse 
scandal to an 'activated' and rapidly 'amplifying' scandal that retrofitted Sir Jimmy Savile as a 'prolific sexual predator' and the BBC as a mendacious institution that knowingly connived at his offences. Whilst UK newspapers had periodically reported allegations against Savile for years, normative, organisational and journalistic priorities appear to have prevented any further journalistic investigation. Even with the raft of new accusations following Savile's death, journalistic reticence ensured that the scandal remained 'latent'. It was not until the ITV Exposure team successfully named Savile as a 'prolific sexual predator' and directly implicated the BBC that the 'latent' scandal was 'activated'. In recognition of an agendasetting role that opened a floodgate of disclosures and revelations, the documentary won awards at the The Royal Television Society and the London Press Club. Exposure: the Other Side of Jimmy Savile was also short-listed for a BAFTA in 2013.

Our research indicates that, in a climate where guilt is assumed, denial of CSA allegations triggers 'trial by media'. The Savile case thus provides a remarkable demonstration of how the 'activation' of a hard news scandal empowers the news media, simultaneously validating their public watchdog role and increasing audiences. Scandals engage the public by exposing the vices of power and fame. They invite news consumers to fulminate against hypocrites who appear to believe they can violate key normative boundaries with impunity. However, institutional CSA scandals are distinctive in the combination and interaction of the inferential structures that shape their construction as news. 'Sexual predator' and 'institutional cover-up' are each highly resonant on their own and connect with powerful sources of contemporary fear, anxiety, mistrust and outrage. But it is in their mutually amplifying interaction - the abuse of the innocent by the powerful and corrupt in a culture of impunity and denial - that institutional CSA scandals find their full moral, cultural and political force. Because of their immediate and devastating impact, institutional CSA scandals can redefine reality, transforming public perceptions of individuals and organisations and reshaping cultural attitudes towards 'official' power. As we have shown, within one week of the scandal's activation, the enduring and remarkably resilient public biography of Sir Jimmy Savile was rewritten. Through the moral work of scandal, he was transformed publicly and incontrovertibly into a monster, and the BBC was subjected to a sustained 'trial by media' across all sections of the UK press on charges of institutional failure, denial and cover-up. 
The Savile scandal sparked a crisis of leadership at the BBC that led to the resignation of George Entwistle, the Director General, the reorganisation of BBC news reporting, and multiple inquiries into the corporation's failings both before and after the scandal's activation. Under intense news media pressure, senior BBC personnel have accepted that they were 'in denial' about Sir Jimmy Savile's offending. Mortified BBC representatives have offered abject public apologies to Savile's victims, and conceded liability for the need to compensate anyone he assaulted on BBC premises. A humiliated BBC has acknowledged that public confidence in the quality and independence of its journalism had in 2013 fallen to its lowest level for seven years. The corporation's ideological adversaries in the national press have explained its 'institutional failure' in terms of irresponsible management, a morally bankrupt celebrity culture and a lavish funding model. Even newspapers normally supportive of the BBC have asked how Savile was for decades allowed to offend, and why the $\mathrm{BBC}$ ignored the reputational risk posed by the activating scandal.

At the time of writing the scandal was still 'amplifying'. According to Scotland Yard, Savile stands accused of 1,350 sexual assaults alleged to have taken place not just on BBC premises, but across hospitals, nightclubs, hotels and his own residences. The police investigation, Operation Yewtree, has resulted in the questioning, and in some cases highprofile arrest and prosecution, of numerous aging BBC celebrities suspected of historic sexual assaults. As the unprecedented investigation continues, the national conversation has been animated by the question 'who will be next?' To date, all of those accused have publicly denied their guilt. All have been subjected to a shaming 'trial by media'. The scandal has triggered official inquiries into police forces that did not act on complaints about Savile and hospitals that allowed Savile to work as a volunteer. According to child protection organisations, the 'Savile effect' has resulted in a dramatic rise in reported offences of child sexual abuse. This in turn has led to new inquiries into institutional CSA in residential homes in north Wales and London. When published, the numerous reports into the Savile scandal will result in intensive news media scrutiny for further scandalous revelations and evidence of institutional cover-ups. The arrest and prosecution of celebrities for historic sex crimes has prompted British society to reflect on how the cultural milieu of the 1970s, and the sexualisation of teenage girls in particular, allowed Sir Jimmy Savile to offend with impunity. Equally significantly, the 'justice' message being communicated through these 
investigations, arrests and prosecutions is that, in an age of 'trial by media', historic sex crimes are not historic. 


\section{References}

Allen, H. and Savigny, H. 2012 'Selling scandal or ideology? The politics of business crime coverage', European Journal of Communication 27(3): 278-290.

Angelides, S. 2005 'The emergence of the paedophile in the late twentieth century', Australian Historical Studies 36(126): 272-295.

Apostolidis, P. and Williams, J. 2004 Public affairs : politics in the age of sex scandals, Durham, N.C.: Duke University Press.

Barter, C. 1998 'Investigating institutional abuse of children: an exploration of the NSPCC experience' NSPCC Policy Practice Research Series, London.

Basinger, S. and Rottinghaus, B. 2012 'Skeletons in the White House Closets: An Empirical Investigation into Modern Presidential Scandals', Political Science Quarterly 127(2): 213-239.

Bellamy, A. 2012 How's About That Then?: the Authorised biography of Jimmy Savile, Leeds: Great Northern Books.

Bromley, M. 1998 'The 'Tabloiding' of Britain: 'Quality' Newspapers in the 1990s', in M. Bromley and H. Stephenson (eds) Sex Lies and Democracy: The Press and the Public London Longman

Campus, D. 2010 'Mediatization and Personalization of Politics in Italy and France: The Cases of Berlusconi and Sarkozy', International Journal of Press/Politics 15(2): 219-235.

Castells, M. 2009 Communication power, Oxford: Oxford University Press.

Cavender, G., Gray, K. and Miller, K. W. 2010 'Enron's perp walk: Status degradation ceremonies as narrative', Crime, Media, Culture 6(3): 251-266.

Cepernich, C. 2008 'Landscapes of Immorality: Scandals in the Italian Press (1998 - 2006)', Perspectives on European Politics and Society 9(1): 95-109.

Clark, A. 2004 Scandal : the sexual politics of the British constitution, Princeton, N.J.: Princeton University Press.

Cohen, S. 2001 States of denial : knowing about atrocities and suffering, Cambridge: Polity.

Corby, B., Doig, A. and Roberts, V. 1998 'Inquiries into child abuse', Journal of Social Welfare and Family Law 20(4): 377-395.

Critcher, C. 2002 'Media, Government and Moral Panic: the politics of paedophilia in Britain 2000-1', Journalism Studies 3(4): 521-535.

Davidson, J. C. 2008 Child sexual abuse : media representations and government reactions, Milton Park, Abingdon, UK ; New York, NY: Routledge-Cavendish.

Department of Health 1991 'Child Abuse: A Study of Inquiry Reports 1980-89', London. Department of Health and Social Services 1982 'Child Abuse: A Study of inquiry Reports 1973-8', London.

Entman, R. M. 2012 Scandal and silence : media responses to presidential misconduct, Cambridge ; Malden, MA: Polity.

Franklin, B. 1997 Newszak and news media, London ; New York: Arnold.

Franklin, B. and Parton, N. 1990 Social work, the media and public relations, London:

Routledge.

Gamson, J. 2001 'Normal Sins: Sex Scandal Narratives as Institutional Morality Tales', Social Problems 48(2): 185-205.

Gardner, F. 2012 'DEFENSIVE PROCESSES AND DECEPTION: AN ANALYSIS OF THE RESPONSE OF THE INSTITUTIONAL CHURCH TO DISCLOSURES OF CHILD SEXUAL ABUSE', British Journal of Psychotherapy 28(1): 98-109. 
Garfinkel, H. 1956 'Conditions of Successful Degradation Ceremonies', American Journal of Sociology 61(5): 420-424.

Garment, S. 1991 Scandal : the crisis of mistrust in American politics, 1st Edition, New York: Times Books.

Greer, C. 2012 Sex Crime and the Media: Sex Offending and the Press in a Divided Society, London: Routledge.

Greer, C. and Mclaughlin, E. 2010 'We Predict a Riot? Public Order Policing, New Media Environments and the Rise of the Citizen Journalist ', British Journal of Criminology 50(6): 1041-1059.

- 2011 'Trial by media: Policing, the News 24-7 News Mediasphere, and the Politics of Outrage', Theoretical Criminology 15(1): 23-46.

- 2012a 'Media Justice: Madeleine McCann, Intermediatization and 'Trial by Media' in the British press', Theoretical Criminology 16(4): 395-416.

$-2012 b$ 'This is not Justice': Ian Tomlinson, Institutional Failure and the Press Politics of Outrage', British Journal of Criminology 52(2): 274-293.

- 2012c 'Trial by Media: Phone-hacking, Riots, Looting, Gangs and Police Chiefs', in J. Peay and T. Newburn (eds) Policing, Politics, Culture and Control: Essays in Honour of Robert Reiner, London: Hart.

Hood, C. 2011 The blame game : spin, bureaucracy, and self-preservation in government, Princeton, N.J.: Princeton University Press.

Jenkins, P. 1992 Intimate enemies : moral panics in contemporary Great Britain, New York: Aldine de Gruyter.

Katz, J. 1979 'Concerted Ignorance - The Social Construction of Cover-Up', Urban Life 8(3): 295-316.

Kipnis, L. 2010 How to become a scandal : adventures in bad behavior, 1st Edition, New York: Metropolitan Books.

Kitzinger, J. 1996 'Media Constructions of Sexual Abuse Risks', Child Abuse Review 5(5): 319333.

- 2001 'Transformations of public and private knowledge: audience research, feminism and the experience of childhood sexual abuse', Feminist Media Studies 1(1): 91-104.

- 2004 Framing Abuse: Media Influence and Public Understanding of Sexual Violence Against Children, London: Pluto.

Kovach, B. and Rosenstiel, T. 1999 Warp speed : America in the age of the mixed media culture, New York: Century Foundation Press.

La Fontaine, J. S. 1990 Child sexual abuse, Cambridge: Polity in association with Basil Blackwell.

Lang, K. and Lang, G. 1955 'The Inferential Structure of Political Communications: A Study in Unwitting Bias', Public Opinion Quarterly 19(2): 168-183.

Lofland, J. 1969 Deviance and identity, Englewood Cliffs, N.J.,: Prentice-Hall.

Lull, J. and Hinerman, S. 1997 Media scandals : morality and desire in the popular culture marketplace, Oxford: Polity.

Marion, N. E. 2010 The politics of disgrace : the role of political scandal in American politics, Durham, N.C.: Carolina Academic Press.

Marr, A. 2004 My trade : a short history of British journalism, London: Macmillan.

Moore, C. 1996 The Kincora scandal : political cover-up and intrigue in Northern Ireland, Dublin: Marino Press. 
Postman, N. 2005 Amusing ourselves to death : public discourse in the age of showbusiness, London: Penguin.

Puglisi, R. and Snyder, J. M. 2011 'Newspaper Coverage of Political Scandals', The Journal of Politics 73(3): 931-950.

Radford, L., Corral, S., Bradley, S., Fisher, H., Bassett, C., Howat, N. and Collishaw, S. 2011 'Child Abuse and Neglect in the UK Today', London: NSPCC.

Sabato, L. 1991 Feeding frenzy : how attack journalism has transformed American politics, New York: Free Press.

Sabato, L., Stencel, M. and Lichter, S. R. 2000 Peepshow : media and politics in an age of scandal, Lanham, Md.: Rowman \& Littlefield Publishers.

Savile, J. 1974 As It Happens, London: Barrie and Jenkins.

Schickel, R. 2000 Intimate strangers : the culture of celebrity in America, Chicago: Ivan R.

Dee.

Sherman, L. W. 1978 Scandal and reform : controlling police corruption, Berkeley: University of California Press.

Silverman, J. and Wilson, D. 2002 Innocence betrayed : paedophilia, the media and society, Cambridge: Polity.

Sykes, G. and Matza, D. 1957 'Techniques of Neutralization: A Theory of Delinquency', American Sociological Review 22(6): 664-670.

Thompson, J. B. 2000 Political scandal : power and visibility in the media age, Cambridge, Malden, Mass.: Polity Press, Blackwell.

Toepfl, F. 2011 'Managing public outrage: Power, scandal, and new media in contemporary Russia', New Media \& Society 13(8): 1301-1319.

Tumber, H. 1993 'Selling scandal': business and the media', Media, Culture \& Society 15(3): 345-361.

- 2004 'Scandal and Media in the United Kingdom : From Major to Blair', American Behavioral Scientist 47(8): 1122-1137.

Waterhouse, S. R. 2012 'Lost in Care: Report of the Tribunal of Inquiry into the Abuse of children in the former County Council areas of Gwynedd and Clwyd since 1974', London. Wilson, J. 2010 'Star testing: the emerging politics of celebrity gossip', The Velvet Light Trap 65(1): 25-38.

Zerubavel, E. 2006 The elephant in the room : silence and denial in everyday life, Oxford ; New York: Oxford University Press. 